\title{
Immunological Regulation of Synaptic Transmission in Isolated Guinea Pig Autonomic Ganglia
}

\author{
Daniel Weinreich* and Bradley J. Undem ${ }^{*}$ \\ *Department of Pharmacology and Experimental Therapeutics, University of Maryland School of Medicine, Baltimore, Maryland 21201; \\ ${ }^{\ddagger}$ Department of Medicine, Division of Clinical Immunology, Johns Hopkins University School of Medicine at The Good Samaritan \\ Hospital, Baltimore, Maryland 21239
}

\begin{abstract}
We have attempted to identify a role for mast cells in autonomic ganglia by examining the effects of antigen challenge on mast cell-associated mediator release and synaptic transmission through the superior cervical ganglion isolated from ovalbuminsensitized guinea pigs. Ovalbumin induced the release of $7.9 \mathrm{ng}$ of histamine, $40 \mathrm{pg}$ of immunoreactive sulfidopeptide-leukotriene, and $140 \mathrm{pg}$ of immunoreactive- $\mathrm{PgD}_{2}$ per ganglion. Ovalbumin produced long-lasting potentiation $(51 \pm 4 \%$, mean $\pm \mathrm{SEM}, n=66$ ) of synaptic transmission, the protracted nature of which could not be mimicked by exogenous histamine $\left(10^{-5} \mathrm{M}\right)$. Selective histamine $\mathrm{H1}$ antagonists inhibited the antigen-induced potentiation, but did not reverse it when added any time after antigen exposure. These results indicate that immunologic activation of mast cells can directly potentiate neurotransmission in sympathetic ganglia. Histamine appears to be a mediator involved in the induction of antigen-induced potentiation of synaptic transmission, but alone cannot account for the long term nature of this phenomenon.
\end{abstract}

\section{Introduction}

Immunologic activation of mast cells and the subsequent release of inflammatory mediators is thought to be a pivotal event in an allergic response (1). It is generally recognized that alterations in autonomic neuroeffector transmission also contribute to the pathology of allergic disease (2). For the most part, how mast cells and nerves relate to allergic disease have been investigated separately, yet the fact that mast cells reside in peripheral nervous tissues such as autonomic ganglia $(3,4)$, suggests that there may be direct communication between these two cell types.

The present experiments were designed to test two hypotheses: (a) that ganglion-associated mast cells can be actively sensitized and immunologically activated to release inflammatory mediators, and $(b)$ that immunologic activation of ganglionassociated mast cells influences the physiology of autonomic

Address reprint requests to Dr. Weinreich.

Presented in preliminary form at the Annual Meeting of the Society for Neuroscience, Washington, DC. Antigen-induced long-term potentiation (A-l.t.p.) in guinea pig superior cervical ganglia (SCG) in vitro. Received for publication 1 December 1986.

J. Clin. Invest.

(c) The American Society for Clinical Investigation, Inc.

0021-9738/87/05/1529/04 \$1.00

Volume 79, May 1987, 1529-1532 ganglia. We observed that superior cervical ganglia (SCG) ${ }^{1}$ isolated from actively sensitized guinea pigs release mast cell-associated mediators when exposed to antigen. Furthermore, profound and enduring changes in ganglionic synaptic neurotransmission are produced when sensitized SCG are antigenically stimulated. The results suggest that endogenous mast cells can affect the physiology of autonomic neurons. Such neuroimmunological interaction could underlie some of the neurogenic involvement in allergic diseases such as certain types of bronchial asthma.

\section{Methods}

Male albino guinea pigs weighing $300-500 \mathrm{~g}$ were actively sensitized by intraperitoneal injections of ovalbumin (OVA; chicken egg albumin, grade V; Sigma Chemical Co., St. Louis, MO, $10 \mathrm{mg} / \mathrm{kg}$ ) on days 1,3 , and 5 (5). Beginning $21 \mathrm{~d}$ after the last injection, SCG were isolated from control or OVA-sensitized guinea pigs and trimmed of blood vessels and loose connective tissue. Tissue was incubated $60 \mathrm{~min}$ in $1 \mathrm{ml}$ of Locke solution (composition in $\mathrm{mM}$ ): $\mathrm{NaCl}, 136 ; \mathrm{KCl} 5.6 ; \mathrm{MgCl}_{2}, 1.2$; $\mathrm{CaCl}_{2}, 2.2 ; \mathrm{NaH}_{2} \mathrm{PO}_{4}, 1.2 ; \mathrm{NaHCO}_{3}, 14.3 ;$ dextrose 11 and choline $10^{-2}$ maintained at $37^{\circ}$ or $24^{\circ} \mathrm{C}$ and equilibrated with $95 \% \mathrm{O}_{2} / 5 \% \mathrm{CO}_{2}(\mathrm{pH}$ range, 7.2 to 7.4). Ganglia were incubated for an additional $30 \mathrm{~min}$ in the absence or presence of OVA and the amounts of histamine released into the medium and remaining in the tissue were quantified by automated fluorometry (6). The tissue histamine content was determined by placing the ganglion in $1 \mathrm{ml} 0.4 \mathrm{~N}$ perchloric acid and incubating for $15 \mathrm{~min}$ in a hot water bath. In several experiments histamine was also measured by radioenzymatic assay (7); both methods showed similar histamine values. The amounts of sulfidopeptide leukotriene and prostaglandin $\mathrm{D}_{2}\left(\mathrm{PGD}_{2}\right)$ released into the medium were quantified by radioimmunoassays as described by Aharony et al. (8) and Adkinson (9), respectively. The amounts of leukotriene $\mathrm{C}_{4}\left(\mathrm{LTC}_{4}\right), \mathrm{LTD}_{4}$, and $\mathrm{LTE}_{4}$ required to inhibit $\left[{ }^{3} \mathrm{H}\right] \mathrm{LTC}_{4}$ (New England Nuclear) binding $50 \%$ were $0.18,0.30$, and $0.37 \mathrm{pmol} / 0.1 \mathrm{ml}$, respectively. The amount of $\mathrm{PGD}_{2}$ required to inhibit $\left[{ }^{3} \mathrm{H}\right] \mathrm{PGD}_{2}$ binding $50 \%$ was $\sim 0.1 \mathrm{pmol} / 0.1 \mathrm{ml}$. The antibodies used have been shown to have little cross-reactivity $(<1 \%)$ with other available cyclooxygenase and lipoxygenase products $(8,9)$. All values represent the mean \pm SEM and have been corrected for spontaneous release, which was either not detectable or $<5 \%$ of stimulated release. The time course of antigen-induced efflux of histamine from isolated SCG superfused at $2 \mathrm{ml} / \mathrm{min}$ was determined by measuring the amount of histamine in aliquots of superfusates collected at 1-min intervals.

For electrophysiological measurements, trimmed SCG were placed in a $300-\mu 1$ recording chamber continuously irrigated $(2.0 \mathrm{ml} / \mathrm{min})$ with

1. Abbreviations used in this paper: CAP, compound action potentials; CST, cervical sympathetic nerve trunk; $\mathrm{LTC}_{4}$, leukotriene $\mathrm{C}_{4}$; OVA, ovalbumin; SCG, superior cervical ganglia. 


\begin{tabular}{|c|c|c|c|c|c|c|c|c|}
\hline \multirow[b]{2}{*}{ Preparation } & \multirow[b]{2}{*}{ Temperature } & \multirow[b]{2}{*}{$\begin{array}{l}\text { Histamine } \\
\text { content }^{*}\end{array}$} & \multicolumn{5}{|c|}{ Release per SCG evoked by $10 \mu \mathrm{g} / \mathrm{ml}$ OVA } & \multirow[b]{2}{*}{$n$} \\
\hline & & & Histamine & $n$ & $\mathrm{PGD}_{2}^{*}$ & $n$ & $\begin{array}{l}\text { Sulfidopeptide } \\
\text { leukotriene' }\end{array}$ & \\
\hline SCG (sensitized) & $37^{\circ} \mathrm{C}$ & $22 \pm 1.6 \mathrm{ng}$ & $7.9 \pm 0.6 \mathrm{ng}$ & 11 & $140 \pm 17 \mathrm{pg}$ & 9 & $44 \pm 8 \mathrm{pg}$ & 6 \\
\hline SCG (unsensitized) & $37^{\circ} \mathrm{C}$ & $24 \pm 3.0 \mathrm{ng}$ & $<1.0 \mathrm{ng}$ & 4 & $<17.5 \mathrm{pg}$ & 4 & $\mathrm{ND}^{\prime \prime}$ & - \\
\hline SCG (sensitized) & $25^{\circ} \mathrm{C}$ & $21 \pm 0.6 \mathrm{ng}$ & $<1.0 \mathrm{ng}$ & 5 & $<17.5 \mathrm{pg}$ & 2 & ND" & - \\
\hline
\end{tabular}

* SCG were isolated from unsensitized or actively sensitized animals, trimmed of visible blood vessels and excess connective tissue, and incubated at $37^{\circ}$ or $25^{\circ} \mathrm{C}$ in $1 \mathrm{ml}$ buffer solution. The ganglia were challenged with ovalbumin for 30 min and the mediator content of the supernatant was quantified as described in Methods. All values represent mean \pm SEM for $n$ observations. ${ }^{\ddagger}$ Values represent released plus residual histamine.

${ }^{8}$ For experiments quantifying the release of immunoreactive $\mathrm{PGD}_{2}$ and sulfidopeptide leukotrienes, ganglia from 3 animals were pooled in each experiment (6 ganglia per $1 \mathrm{ml}$ sample). "ND, not done.

Locke solution at $37^{\circ}$ or $25^{\circ} \mathrm{C}$. Compound action potentials (CAP) were recorded with suction electrodes placed on a loop of the preganglionic cervical sympathetic nerve trunk (CST) about $5 \mathrm{~mm}$ proximal to the SCG and on the superior postganglionic branch. A third suction electrode was positioned on the distal cut end of the CST to deliver preganglionic stimuli (rectangular current pulses: $0.2 \mathrm{~Hz}, 150-500 \mu \mathrm{s}$ ). Postganglionic CAPs were occasionally evoked nonsynaptically by placing a stimulating suction electrode on the body of the SCG. In these experiments synaptically evoked CAPs were eliminated by the addition of $5 \mathrm{mM}$ hexamethonium. CAPs were dc-amplified, bandpass $0-10 \mathrm{KHz}$. The number of synaptically activated postganglionic fibers was adjusted to $\sim 50 \%$ of maximum by either reducing the intensity and/or the duration of preganglionic stimuli or adding $0.5-1 \mathrm{mM}$ hexamethonium to the superfusate. Similar OVA-induced changes were observed with either method. Because lowering extracellular calcium can depress OVA-induced mediator release, we did not utilize this method to reduce the magnitude of synaptic transmission.

Responses were stored on a Racal FM instrumentation tape recorder and subsequently photographed from a storage oscilloscope. The amplitude of the CAP was measured as the distance between peaks of the initial diphasic deflections. After $\sim 10 \mathrm{~min}$ the amplitude of the evoked CAPs stabilized and remained essentially constant for $>3 \mathrm{~h}$.

For light microscopy, SCG were fixed in isotonic formaldehyde acetic acid, embedded in paraffin and cut into 6- $\mu \mathrm{M}$ serial sections. Mast cells were visualized by toluidine blue staining at acid $\mathrm{pH}$ and counted in every 10th section as previously described (4).

\section{Results}

Histamine, immunoreactive prostaglandin $D_{2}$ and immunoreactive sulfidopeptide leukotrienes were liberated from isolated guinea pig SCG following specific antigen challenge (Table I). Release was temperature sensitive and was dependent on sensitization to the specific antigen (OVA). The onset of histamine release was rapid ( $<2 \mathrm{~min}$ ) and was essentially complete within $10 \mathrm{~min}$ of antigen challenge (Fig. 1). The threshold OVA concentration for histamine release was $\sim 0.01 \mu \mathrm{g} / \mathrm{ml}$. The magnitude and time course of OVA-induced histamine release from the SCG were similar to those reported from isolated guinea pig lung parenchyma, trachea and heart $(5,10)$.

Guinea pig SCG from sensitized animals contained $\sim 700$ toluidine blue stainable mast cells, which is consistent with our previous observations (4). Antigen-challenged SCG contained $<50 \%$ of the number of stainable mast cells found in paired contralateral controls or SCG from nonsensitized animals ( $n$
$=3)$. These data suggest that ganglionic mast cells may be one source of the immunologically induced mediator release shown in Table I.

To determine whether OVA alters the physiology of the SCG, we examined the efficacy of ganglionic synaptic transmission by monitoring the amplitude of the postganglionic CAP in the superior postganglionic nerve. Within 1-2 min after adding OVA

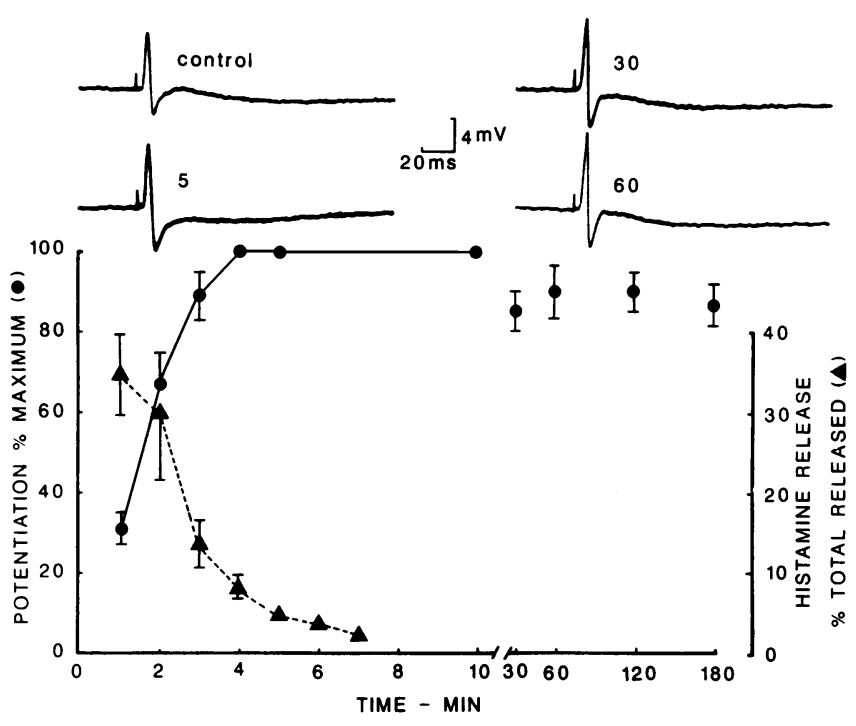

Figure 1. Time course of antigen-induced histamine release and potentiation of synaptic transmission in isolated guinea pig SCG. Before antigen challenge ganglionic transmission was made submaximal by reducing the duration of the preganglionic stimulating pulse. Ovalbu$\min , 10 \mu \mathrm{g} / \mathrm{ml}$, was superfused through the recording chamber for 5 min beginning at time zero indicated on the abscissa. Ovalbumin challenge induced a potentiation of the postganglionic compound action potential amplitude (closed circles) that reached a maximum by $5 \mathrm{~min}$ and lasted for several hours. By contrast ovalbumin-induced histamine release (closed triangles) into the superfusate was maximal at 2 min and subsequently declined to undetectable values by $10 \mathrm{~min}$. Each data point represents mean $\pm \mathrm{SE}$ values from six ganglia. SE bars are within some symbols. Maximum ovalbumin-induced potentiation of the CAP was $45.3 \pm 5 \%$. Maximum ovalbumin-induced histamine release was $32 \pm 1 \%$ endogenous stores. Sample records are representative postganglionic compound action potentials recorded at time (in minutes) relative to the addition of antigen. 
$(0.01-10 \mu \mathrm{g} / \mathrm{ml})$ to the superfusate, the amplitude of the postganglionic CAP increased noticeably, reaching a maximum within 5 to $10 \mathrm{~min}$. The sample records shown in Fig. 1 illustrate the effect of antigen challenge on the postganglionic CAP. In this experiment, the amplitude of the postganglionic CAP increased $\sim 42 \%$. In 66 ganglia challenged with $10 \mu \mathrm{g} / \mathrm{ml}$ OVA, the increase in the postganglionic CAP averaged $51 \pm 4 \%$ (mean \pm SEM; range $<10$ to $180 \%$ ). Antigen had no measurable effect in about $5 \%$ of the ganglia. A particularly striking feature of the OVA-induced potentiation was that in about $75 \%$ of the preparations it persisted essentially unchanged during subsequent wash with OVA-free solutions for at least $1 \mathrm{~h}$. When potentiation was followed for periods greater than $1 \mathrm{~h}$, it persisted up to $3 \mathrm{~h}$, the longest time period examined (Fig. 1).

In eight experiments, the waveform of the preganglionic CAP was monitored from a loop of preganglionic nerve sucked into a second recording electrode. Although OVA application increased the amplitude of the postganglionic CAP, it did not measurably change the waveform of the preganglionic CAP. Larger postganglionic CAP thus arises from a recruitment of additional postganglionic neurons. Conduction velocity and time to peak amplitude of the postganglionic CAP were examined by superimposing control and potentiated CAPs at fast oscilliscope sweep speeds. Neither parameter was measurably changed by antigen challenge indicating that the recruited postganglionic neurons belong to the same class. Also, antigen treatment had no effect on the postganglionic CAPs evoked nonsynaptically ( $n$ $=3$; see Methods).

A variety of control experiments were performed to examine the specificity of the OVA-induced changes in ganglionic transmission. The amplitude of the synaptically generated postganglionic CAP was not measurably altered under the following conditions: ( $a$ ) perfusion of SCG from nonsensitized guinea pigs with $10 \mu \mathrm{g} / \mathrm{ml} \mathrm{OVA}(\mathrm{n}=9)$; $(b)$ perfusion of SCG from sensitized animals with $10 \mu \mathrm{g} / \mathrm{ml}$ human serum albumin $(n=5)$ or bovine serum albumin $(n=4)$; $(c)$ perfusion of SCG from sensitized animals with $10 \mu \mathrm{g} / \mathrm{ml} \mathrm{OVA} \mathrm{at} 25^{\circ} \mathrm{C}$ for $15 \mathrm{~min}(n=5)$; OVA does not induce significant mediator release at $25^{\circ} \mathrm{C}$ (Table I).

We tested several mast cell-associated mediators for their ability to mimick OVA effects on ganglionic transmission. Bath application of $10^{-7} \mathrm{M}$ leukotriene $\mathrm{C}_{4}$ or leukotriene $\mathrm{D}_{4}$ did not affect the CAP amplitude in SCG from OVA-sensitized animals. Inhibiting prostaglandin synthesis with indomethacin $5 \times 10^{-6}$ $M$ did not block antigen-induced increases in ganglionic transmission $(n=6)$. Bath application of $10^{-5} \mathrm{M}$ histamine increased the postganglionic CAP by $18 \pm 6 \%$ (mean \pm SEM, $n=6)$, higher histamine concentrations $\left(10^{-4} \mathrm{M}\right)$ produced no greater effects. Histamine-induced potentiation of the postganglionic CAP was effectively antagonized by $10^{-6} \mathrm{M}$ pyrilamine or diphenhydramine $(n=5)$, but not by $10^{-5} \mathrm{M}$ cimetidine suggesting that it was mediated by histamine $\mathrm{H} 1$ receptors.

To discern whether histamine was involved in antigen-induced potentiation of the postganglionic CAP, we examined the effect of histamine receptor antagonists. Histamine $\mathrm{H} 1$ receptor antagonists (pyrilamine and diphenhydramine) blocked potentiation when antigen was added in their presence, whereas cimetidine did not (Table II). These drugs had no effect on antigeninduced histamine release from the SCG. If either pyrilamine or diphenhydramine were added after antigen challenge, they were completely ineffective at reversing the potentiation of the CAP. Furthermore, unlike antigen-induced potentiation, his-
Table II. Effects of Histamine Receptor

Antagonists on Antigen-induced Increases in the

Postganglionic Compound Action Potential

\begin{tabular}{lcr}
\hline & $\begin{array}{l}\text { OVA-induced increase of } \\
\text { the postganglionic CAP* }\end{array}$ & N \\
\hline Control (no antagonist) & $51 \pm 4 \%$ & 66 \\
Pyrilamine $10^{-6} \mathrm{M}^{\ddagger}$ & $5 \pm 4 \%$ & 6 \\
Diphenhydramine $10^{-5} \mathrm{M}^{\ddagger}$ & $8 \pm 5 \%$ & 6 \\
Cimetidine $10^{-5} \mathrm{M}$ & $60 \pm 20 \%$ & 4 \\
\hline
\end{tabular}

* Potentiation was produced by $10 \mu \mathrm{g} / \mathrm{ml}$ ovalbumin. Percentage increase in the postganglionic compound action potential (CAP) amplitude evoked by antigen challenge was calculated as: (OVA challenged CAP) $-($ control CAP $) /($ Control CAP) $\times 100 \%$. Values represent the mean \pm SEM of $n$ observations.

¥ These antagonists had no effect on the CAP when added after antigen challenge $(n=6)$. OVA-induced potentiation of transmission through contralateral ganglia not treated with diphenhydramine or pyrilamine was not significantly different from the control value.

tamine-induced potentiation reversed to control levels within 2 to $10 \mathrm{~min}$ after switching to histamine-free solutions. These pharmacologic observations plus the fact that histamine was no longer detectable in the supernatants $10 \mathrm{~min}$ after antigen challenge (Fig. 1) suggest that histamine is a necessary mediator via $\mathrm{H} 1$ receptor interactions for initiating antigen-induced potentiation, but it alone is not sufficient to account for the long-term persistence of antigen-induced potentiation.

\section{Discussion}

Interactions between the immune and nervous systems have received increasing attention in recent years. With respect to immediate hypersensitivity reactions, neurotransmitters and neuropeptides can influence antigen-induced mast cell mediator release $(11,12)$ and mast cell activation is associated with an increase in impulse traffic through afferent sensory nerves (13). The results in the present report support the concept of communication between the immune and nervous system by demonstrating that antigenic activation of mast cells can lead to profound effects on neurotransmission through autonomic ganglia.

That mast cells are responsible for the observed antigeninduced increase in synaptic transmission in the superior cervical ganglia (SCG) is supported by several lines of evidence. First, the SCG is endowed with 500-1,000 mast cells which, based on morphologic assessment, degranulated upon antigen exposure. Second, challenging the SCG with specific antigen caused the release of the mast cell-associated mediators, histamine, $\mathrm{PGD}_{2}$, and sulfidopeptide leukotrienes. Third, when ganglia were incubated at room temperature, antigen exposure did not induce mast cell activation or changes in synaptic transmission. Finally, pharmacological antagonists of histamine inhibited antigen-induced potentiation of transmission. Although histamine is found in several cell types, mast cells and basophils are generally considered to be the sources of histamine released by antigenic stimulation (1).

Histamine $\mathrm{H} 1$ receptor activation was clearly involved in the antigen-induced increase in ganglionic transmission, but it 
could not by itself account for the maintenance of this potentiation. Exogenous histamine application never evoked longterm changes in ganglionic transmission and histamine receptor antagonists were ineffective at reversing antigen-induced potentiation of the postsynaptic response. Thus, other mediator(s) likely contribute to the long-term nature of this response. There are many mediators involved in inflammatory reactions initiated by mast cell activation (14). Sulfidopeptide leukotrienes and prostaglandins are mediators commonly associated with immediate hypersensitivity reactions (14); however, we found no evidence for the involvement of these substances in antigeninduced potentiation of ganglionic neurotransmission.

A remarkable characteristic of the antigen-induced increase in ganglionic transmission is that in most ganglia it is only very slowly reversible. This protracted potentiation resembles longterm potentiation induced by brief high frequency presynaptic stimulation in the rat SCG (15) and in the hippocampal formation (16). An important difference between antigen- and neurogenic-induced long-term potentiation is that the former requires no prior synaptic activation. Thus, sustained changes in synaptic transmission in autonomic ganglia can be induced by diverse stimuli. Whether similar or different mechanisms underlie these two forms of long-term potentiation will require further studies.

Our results demonstrate that antigen challenge alters the physiology of autonomic ganglia by modifying synaptic transmission. The contribution of pre- and postsynaptic processes responsible for this phenomenon cannot be determined from extracellular recordings. Thus, future studies in this regard will require microelectrophysiological techniques. Regardless of its mechanism and site of action, antigen-induced increase in synaptic transmission through autonomic ganglia may be an important factor in the pathophysiology of allergic disease. Several investigations have revealed alterations in sympathetic and parasympathetic responsiveness in atopic patients (17). Such observations may be explained at least in part by allergen-induced long term changes in ganglionic synaptic transmission.

\section{Acknowledgments}

The authors thank Dr. Edward Christian for editorial comments and Drs. N. Franklin Adkinson, Jr. (Johns Hopkins University), R. Krell (Stuart Pharmaceuticals, Wilmington, DE) and J. Rokach (Merck-Frosst Labs, Canada) for supplying anti-PGD $\mathrm{P}_{2}$ antibody, anti-sulfidopeptide leukotriene antibody and authentic leukotrienes, respectively.

This work was supported by grants from the National Institutes of Health (NS22069) and The American Lung Association.

\section{References}

1.Metcalfe, D. D., M. Kaliner, and M. A. Donlon. 1981. The mast cell. CRC Crit. Rev. Immunol. 3:23-74.

2. Kaliner, M., J. H. Shelhamer, P. B. Davis, L. J. Smith, and J. C. Venter. 1982. Autonomic nervous system abnormalities and allergy. Ann. Intern. Med. 96:349-357.

3. Olsson, Y. 1968. Mast cells in the nervous system. Int. Rev. Cytol. 24:27-70.

4. Weinreich, D. 1985. Multiple sites of histamine storage in superior cervical ganglia. Exp. Neurology. 90:36-43.

5. Wong, S. K., and C. K. Buckner. 1980. Studies on the beta adrenergic receptors mediating inhibition of antigen-induced histamine release from the lung and heart isolated from the actively sensitized guinea pig. J. Pharmacol. Exp. Ther. 214:152-160.

6. Siraganian, R. P. 1974. An automated continuous-flow system for the extraction and flurometric analysis of histamine. Anal. Biochem. 57: 383-391.

7. Brown, M. J., P. W. Ind, D. A. Barnes, D. A. Jenner, and C. T. Dollery. 1980. A sensitive and specific radiometric method for the measurement of plasma histamine in normal individuals. Anal. Biochem. 109:142-146.

8. Aharony, D., P. Dobson, P. R. Bernstein, E. J. Kugher, R. D. Krell, and J. B. Smith. 1983. Determination of SRS-A release from guinea pig lungs by a radioimmunoassay. Biochem. Biophys. Res. Commun. 117:574-579.

9. Adkinson, N. F. Jr. 1977. Prostaglandin production by human peripheral blood cells in vitro. J. Lab. Clin. Med. 90:1043-1053.

10. Undem, B. J., C. K. Buckner, P. Harley, and F. M. Graziano. 1985. Smooth muscle contraction and release of histamine and slowreacting substance of anaphylaxis in pulmonary tissues isolated from guinea pigs passively sensitized with IgG $_{1}$ or IgE antibodies. Am. Rev. Respir. Dis. 131:260-266.

11. Kaliner, M., R. P. Orange, and K. F. Austen. 1972. Immunologic release of histamine and SRS-A from human lung. IV. Enhancement by cholinergic and $\alpha$-adrenergic stimulation. J. Exp. Med. 136:556-567.

12. Goetzl, E. J., T. Chernov, F. Renold, and D. G. Payan. 1985. Neuropeptide regulation of the expression of immediate hypersensitivity. J. Immunol. 135:802s-805s.

13. Widdicombe, J. G. 1983. Mediators and reflex bronchoconstriction. Eur. J. Respir. Dis. 64:65-87.

14. Schwartz, L. B., and K. F. Austen. 1984. Structure and function of the chemical mediators of mast cells. Prog. Allergy. 34:271-321.

15. Briggs, C. A., T. H. Brown, and D. A. McAfee. 1985. Neurophysiology and pharmacology of long-term potentiation in the rat sympathetic ganglion. J. Physiol. 359:503-521.

16. Bliss, T. V. P., and A. R. Gardner-Medwin. 1973. Long-lasting potentiation of synaptic transmission in the dentate area of the unanaesthetized rabbit following stimulation of the perforant path. J. Physiol. 232:281-356.

17. Casale, T. B. 1983. The role of the autonomic nervous system in allergic disease. Ann. Allergy. 51:423-429. 